\title{
A STUDY ON OPPORTUNITIES AND CONSTRAINTS FACED BY WOMEN ENTREPRENEURS IN E-COMMERCE
}

\author{
G. Lakshmi Priya ${ }^{1}$, Dr. S. Smilee Bose ${ }^{2}$ \\ ${ }^{1}$ Full-Time Research Scholar, Department of Commerce, \\ St. Peter's Institute of Higher Education and Research, \\ St. Peters University, Tamil Nadu, India \\ ${ }^{2}$ Research Supervisor, Associate Professor, Department of Commerce, \\ St. Peter's Institute of Higher Education and Research, \\ St. Peters University, Tamil Nadu, India
}

\begin{abstract}
Women Entrepreneur is a single person or group of persons who take risks to meet their personal goals and are capable of contributing to both their family as well as society. Generally, Women Entrepreneurs has inbuilt quality of being creative and have strong desire to achieve maximum return with their invested capital. Today, Internet has changed the life of women professionally. Number of self-employed women have been increasing rapidly due to advancement in technology. Internet paved the way for evolution of E-Commerce platform for Women Entrepreneurs. Entrepreneurship among women has to be considered as important topic in our society as they act as catalyst for economic prosperity of our nation. The inadequacy of Entrepreneurship among Women may be due to family responsibilities, lack of business knowledge, male domination, self- fear and doubt etc. This paper identifies opportunities available for Women Entrepreneurs in E-Commerce and Challenges faced by Women Entrepreneurs in running their online business. For this, stratified random sample of sixty Women Entrepreneurs who are running their online business has been taken for data collection. Collected data are analysed using Chi-Square test. This research paper reveals that Education qualification of Women Entrepreneurs doing online business has no significant relationship with opportunities faced by Women Entrepreneurs in doing online business and Experience of Women Entrepreneurs in doing online business has no significant relationship with challenges faced by Women Entrepreneurs in doing online business.
\end{abstract}

Keywords: Women Entrepreneurs, E-Commerce, Online Business, Opportunities, Challenges.

Cite this Article: G. Lakshmi Priya, S. Smilee Bose, A Study on Opportunities and Constraints Faced by Women Entrepreneurs in E-Commerce, Journal of Management (JOM), 8 (3), 2021, pp. 1-12.

https://iaeme.com/Home/issue/JOM?Volume $=8 \&$ Issue $=3$ 


\section{INTRODUCTION}

E-Commerce is the place of medium where exchange of goods and services takes place without barriers of time or distance with the use of electronic devices. In recent decades, the usage of E-Commerce has expanded rapidly and it is expected to continue at considerable rate or even accelerate. This is mainly due to high penetration of internet and experience electronic devices. In this modern world, Women Entrepreneurship act as real cause for economic prosperity of our nation which helps in creating employment opportunities, technological advancement, contribution to national income, industrialization, regional development etc.

Women Entrepreneurs represented as Women or group of women who explores idea of starting venture, undertake risks, introduce new innovations, coordinate with others, administrate and control business, make effective decision and problem solving and effective leadership in all aspects of business. E-Commerce has given Women Entrepreneurs to access and opportunity to do business with the capability of technology. Women Entrepreneurs realizes that E-Commerce is an important media for effective advertisement. The benefits of Women Entrepreneurs in using E-Commerce platform for undertaking entrepreneurial activities are ease global reach, lower cost in adoption, ease of identifying and prospecting customers, less time consuming, provides abundant information about products and services to targeted customers and 24/7 working services etc.

\section{OBJECTIVE OF THE STUDY}

This study aimed to examine demographic characteristics of Women Entrepreneurs who have adopted E-Commerce applications in running their business and aimed to find out major challenges faced by Women Entrepreneurs in E-Commerce and to identify and describe the opportunities available to Women Entrepreneurs in E-Commerce.

\section{REVIEW OF LITERATURE}

1. Dr. K. Pushpam and Dr. Thirumal (2020)- "Role of Women Entrepreneurs in Digital Commerce". This study identifies the role of Women Entrepreneurs in E Commerce sector and various challenges faced by them in online industry and E-Commerce sector. Researchers founds the challenges of women entrepreneurs in online business are

i) Finding suitable market,

ii) Retaining customers,

iii) lack of trust,

iv) Inadequacy of funds and

v) Good and effective customer service.

The result shows that lack of trust and inadequacy of funds are the most common problem faced by women entrepreneur in E-Commerce sector.

Dr. Sonia Justin Raj, Mr. Anshul Vyas and Mr. Bhanu Pratap Singh Rathore (2018)- "E Commerce vs Women Entrepreneurs". This study identified the challenges faced by women entrepreneurs in the online e-commerce industry. The challenges are lack of awareness, competition, good supply chain and realisable logistics, Problem in finding suitable market, Finance problem, Problems in retaining customers, Business know-how. It is concluded that Women Entrepreneurs must be educated and have sound technical knowledge.

Mr.B.Manikandan, Dr. N.Kathirvel, D.Kavi priya (2019)- " Challenges and Opportunities for Women Entrepreneurs". This study described opportunities available for encouraging Women Entrepreneurs to use an online platform and various challenges faced by Women who wants to use online platform to start, grow and sustain their business. Financial problem, 
shortage of raw material, stiff competition, lack of motivation, low risk bearing capacity etc. are the problems faced by Women in E-Commerce platforms.

Akhila Pai H (2018)- "Digital Startups and Women Entrepreneurship: A study on status of Women Entrepreneurs in India". This study identified the motive factors and major challenges faced by Women Entrepreneurs in digital market. Global reach, flexibility, huge ROI, absence of middlemen, 24/7 business, secured platform etc. are the motive factors that encourage women to setup digital start-ups. Security issues, stiff competition, lack of training the team, finding suitable market etc. are the challenges faced by women in digital market.

\section{RESEARCH METHODOLOGY}

This study is based on both Primary data and Secondary data. Primary data are collected using Questionnaire. Secondary data are collected through Books, Journals, Websites, and Published articles related to this topic. A sample of sixty women entrepreneurs doing online business has been taken. Sampling is done on the basis of simple and stratified random sampling. Data are analysed by using t Tests for Demographic variables and Chi-Square for Opportunities and challenges faced by women entrepreneurs in doing E Business.

\section{ANALYSIS AND FINDINGS}

By analysing the raw data which was collected through questionnaire, the following results are interpreted.

\subsection{Demographic Profile of Respondents}

\section{Hypothesis}

\section{Null Hypothesis}

$\mathrm{H}_{01}: \mu=$ Average age of the respondents belong to the age group of 25 years- 30 years

$\mathrm{H}_{02}: \mu=$ Average Education Qualification of the respondents have SSLC/HSC

$\mathrm{H}_{03}: \mu=$ Average Martial status of the Respondents are Un Married.

$\mathrm{H}_{04}: \mu=$ Average years of Experience of the respondent have in E-Business is 1-2 years.

$\mathrm{H}_{05}: \mu=$ Average Number of respondents are retailers in E-Business

$\mathrm{H}_{06}: \mu=$ Average Size of the E-Business is Micro level Business

$\mathrm{H}_{07}: \mu=$ Average kind of E-Business run by Women Entrepreneurs is selling jewellery and cosmetics.

Table 1 Shows general profile of Women Entrepreneurs.

1.. The Distribution of Women Entrepreneurs according to the age at the time of survey is given in the below table.

$\mathrm{ndf}=4$; The table value at $5 \%$ level $=2.776$

$\mathrm{H}_{0}$ is accepted at $5 \%$ level since the calculated value of $\mathrm{t}(0.4922)$ is less than $(<)$ the table value of t. Hence, Average age of the respondents belong to the age group of 25years-30 years.

2. The respondents under different levels of education are represented in the below Table ndf 3; The table value at $5 \%$ level 3.182

$\mathrm{H}_{0}$ is accepted at $5 \%$ level. Since the calculated value of $\mathrm{t}(1.0388)$ is less than $(<)$ the table value of t. Hence, Average Education Qualification of the respondents have SSLC/HSC.

3. The marital status of the respondents is classified into married, Un Married, widow and divorcee showed in the below Table.

ndf 3; The table value at $5 \%$ level $=3.182$ 
$\mathrm{H}_{0}$ is accepted at $5 \%$ level. Since the calculated value of $\mathrm{t}(2.55)$ is less than $(<)$ the table value of t. Hence, Average Martial status of the Respondents are Un Married.

4. The Experience of women entrepreneurs in E-Business is shown in the table 1.1

ndf 3; The table value at $5 \%$ level $=3.182$

$\mathrm{H}_{0}$ is accepted at $5 \%$ level. Since the calculated value of $\mathrm{t}(0.53432)$ is less than $(<)$ the table value of t. Hence, Average years of Experience of the respondent have in E-Business is 1-2 years.

5. Ownership Structure of the respondents in doing Online Business has been represented in the table 1.1 .

$\mathrm{ndf}=3$; The table value at $5 \%$ level $=3.182$

$\mathrm{H}_{0}$ is accepted at $5 \%$ level. Since the calculated value of $\mathrm{t}(0.3026)$ is less than $<$ the table value of t. Hence, Average Number of respondents are retailers in E-Business.

6. The Business size of the respondents in E Business is shown in the Table 1.1.

ndf 3; The table value at $5 \%$ level $=3.182$

$\mathrm{H}_{0}$ is accepted at $5 \%$ level. Since the calculated value of $\mathrm{t}(0.552345)$ is less than $(<)$ the table value of t. Hence, Average Size of the E-Business is Micro level Business.

7. Different forms of Business is an essential key to determine the economic performance of women entrepreneurs. In recent times, women entrepreneurs are engaging in different types of E-Business, which provides more benefits to them. Line of activity chosen by entrepreneurs is related to factors like skills, education, finances, and convenience. Table 1.7 shows the kinds of E-Business Activities done by the women entrepreneurs.

ndf 8 ; The table value at $5 \%$ level $=2.306$

$\mathrm{H}_{0}$ is Rejected at 5\% level since the calculated value of $\mathrm{t}(2.78004)$ is greater than (>) the table value of t. Hence, Average kind of E-Business run by Women Entrepreneurs is not selling jewellery and cosmetics

Table 1 Demographic Variables of the Respondents

\begin{tabular}{|c|c|c|c|c|c|c|c|}
\hline S.No & $\begin{array}{c}\text { Demographics } \\
\text { factors }\end{array}$ & Group of Data & $\begin{array}{c}\text { No. of } \\
\text { Respondents }\end{array}$ & $\begin{array}{c}\text { Mean } \\
(\overline{\mathbf{x}})\end{array}$ & $\begin{array}{l}\text { Standard } \\
\text { Deviation }\end{array}$ & $\begin{array}{l}\text { Degree of } \\
\text { Freedom }\end{array}$ & $\begin{array}{c}\text { Test } \\
\text { Statistic } t\end{array}$ \\
\hline 1 & Age & 20 years- 25 years & 27 & \multirow{5}{*}{12} & \multirow{5}{*}{8.124} & \multirow{5}{*}{4} & \multirow{5}{*}{0.4922} \\
\hline & & 25 years- 30 years & 14 & & & & \\
\hline & & 30 years- 35 years & 8 & & & & \\
\hline & & 35 years- 40 years & 6 & & & & \\
\hline & & Above 40 years & 5 & & & & \\
\hline \multirow[t]{4}{*}{2} & Education & SSLC/ HSC & 10 & \multirow{4}{*}{15} & \multirow{4}{*}{8.3366} & \multirow{4}{*}{3} & \multirow{4}{*}{1.0388} \\
\hline & Qualification & Under Graduate & 27 & & & & \\
\hline & & Post Graduate & 18 & & & & \\
\hline & & Professional & 5 & & & & \\
\hline \multirow[t]{4}{*}{3} & Marital Status & Married & 18 & \multirow{4}{*}{15} & \multirow{4}{*}{8.3366} & \multirow{4}{*}{3} & \multirow{4}{*}{1.0388} \\
\hline & & Un Married & 32 & & & & \\
\hline & & Widow & 3 & & & & \\
\hline & & Divorcee & 7 & & & & \\
\hline \multirow[t]{4}{*}{4} & Experience in E- & 0-1 Year & 23 & \multirow{4}{*}{15} & \multirow{4}{*}{6.4807} & \multirow{4}{*}{3} & \multirow{4}{*}{0.53432} \\
\hline & Business & 1-2 Years & 17 & & & & \\
\hline & & 2-4 Years & 15 & & & & \\
\hline & & \begin{tabular}{|l|} 
Above 4 Years \\
\end{tabular} & 5 & & & & \\
\hline \multirow[t]{3}{*}{5} & Ownership & Sole Proprietor & 24 & \multirow[b]{3}{*}{15} & \multirow[b]{3}{*}{5.723} & \multirow[b]{3}{*}{3} & \multirow[b]{3}{*}{0.3026} \\
\hline & Structure & Partnership & 10 & & & & \\
\hline & & \begin{tabular}{|l|} 
Co-operative \\
Business
\end{tabular} & 10 & & & & \\
\hline
\end{tabular}




\begin{tabular}{|c|c|c|c|c|c|c|c|}
\hline & & Retailers & 16 & & & & \\
\hline \multirow[t]{4}{*}{6} & Size of Business & \begin{tabular}{|l|} 
Micro Level \\
Business
\end{tabular} & 12 & \multirow{4}{*}{15} & \multirow{4}{*}{5.723} & \multirow{4}{*}{3} & \multirow{4}{*}{0.3026} \\
\hline & & \begin{tabular}{|l} 
Small Scale \\
Business
\end{tabular} & 31 & & & & \\
\hline & & \begin{tabular}{|l|} 
Medium Level \\
Business
\end{tabular} & 7 & & & & \\
\hline & & \begin{tabular}{|l|} 
Large Scale \\
Business \\
\end{tabular} & 10 & & & & \\
\hline \multirow[t]{9}{*}{7} & Kinds of Business & Online Marketing & 5 & \multirow{9}{*}{6.667} & \multirow{9}{*}{3.3910028} & \multirow{9}{*}{8} & \multirow{9}{*}{2.78004} \\
\hline & & Online Teaching & 8 & & & & \\
\hline & & $\begin{array}{l}\text { Clothing and } \\
\text { Accessories }\end{array}$ & 13 & & & & \\
\hline & & $\begin{array}{l}\text { Online } \\
\text { Consultancy }\end{array}$ & 2 & & & & \\
\hline & & $\begin{array}{l}\text { Online Ticket } \\
\text { Bookings }\end{array}$ & 3 & & & & \\
\hline & & $\begin{array}{l}\text { Catering and } \\
\text { Beverages }\end{array}$ & 6 & & & & \\
\hline & & $\begin{array}{l}\text { Online Health care } \\
\text { services }\end{array}$ & 4 & & & & \\
\hline & & $\begin{array}{l}\text { Jewellery and } \\
\text { Cosmetics }\end{array}$ & 10 & & & & \\
\hline & & $\begin{array}{l}\text { Media and } \\
\text { Entertainment }\end{array}$ & 9 & & & & \\
\hline
\end{tabular}

(Source: Primary Data)

Interpretation: From the above table1.1, shows that

1.Women in the age group of 20 years-25 years are most likely to start their E-business as compared to women in the age group of 25 years- 30 years and 30 years 35 years. Women in the age of 35 years- 40 years and above 40 years are less in favour of starting their E-business.

2.Majority of respondents are highly educated in Under Graduate (35\%) and Post Graduate (30\%) than in high schools $(17 \%)$ and professional $(8 \%)$. Thus, respondents have a good knowledge of facilities in E-Business.

3. Most of the women are Un Married (53\%). Women are most likely to start their E- business before marriage.

4. Most of the women have less than one year of experience (38\%). This shows that Women are most likely to start their E-business recent times.

5. Most of the women Entrepreneurs in E-Business are Sole Proprietor(40\%). This shows that Women Entrepreneurs are most likely to be owned and controlled by herself alone.

6. Most of the women Entrepreneurs have Small scale E-Business (52\%). This shows that Women Entrepreneurs are most likely to start small scale business because with the idea of minimum investment and maximum profits

7. Majority of women are involved in online clothing business $(22 \%)$ followed by jewellery and cosmetics (17\%), Media and Entertainment(15\%), online teaching(13\%), catering services(10\%), Online Marketing (8\%)and less involved in online health care services $(6 \%)$, Tourism services $(5 \%)$ and consultancy activities $(4 \%)$. 


\subsection{Opportunities and Constraints of E-Commerce on Women Entrepreneurs}

\subsubsection{Opportunities for Women Entrepreneurs in E-Commerce}

E-Commerce is the online market place which gives Women Entrepreneurs flexibility in conducting their business from anywhere and at any time according to their convenience. The main benefit of E-Commerce on Entrepreneurs is that it can be used to spread their product messages to large mass of audience. Another benefit is the Cost effective and convenient medium to connect buyers and suppliers around the world.

- Expand Business reach: Products and services are readily available to the customers with the help of internet. One of the greatest benefit of internet is translation. E-Business does not have to make a site for every language. With the right marketing, every consumer around the world can find the website, product information with confirm purchase.

- Time and cost Saving: Entrepreneurs can save a lot of costs and time in managing E Business. Instead of running physical store, an online store offers them the option to receive orders online, accept payments, ship product and reach to the customers available all across the world.

- Increasing customer base: Customers are the real assets for every business. Women in E Business doesn't need to worry about the global reach of customers, people around the world have access to their products and can come back at any time.

- Rise in sales: E- Business will have more sales with high profit margin as compared to Physical store business. Entrepreneurs can redistribute money to make the consumer Shopping experience faster and more efficient.

- 24/7 days: Even during the natural disasters/ temporary close down of business, online business is open for 24/7 every day of the year that increases their profits.

- Cash less transaction: Payments are received with card, it involves instant transactions with out delayed in payments.

Table 2 Opportunities for Women Entrepreneurs in E-Commerce

\begin{tabular}{|l|c|c|}
\hline \multicolumn{1}{|c|}{ Benefits of E-Commerce } & No. of Respondents & Percentage \\
\hline Ease Global Reach & 12 & $20 \%$ \\
\hline Greater Flexibility & 8 & $13.33 \%$ \\
\hline Profitability & 9 & $15 \%$ \\
\hline Absence of Middlemen & 4 & $7 \%$ \\
\hline Ease in Communication & 5 & $8 \%$ \\
\hline Faster Processing of transaction & 2 & $3 \%$ \\
\hline Ability to do multitasks & 4 & $7 \%$ \\
\hline 24/7 Business & 5 & $8 \%$ \\
\hline Ease access of funds & 8 & $13.33 \%$ \\
\hline Tax Holiday for 3 years & 3 & $5 \%$ \\
\hline Total & 60 & $100 \%$ \\
\hline
\end{tabular}

(source: Primary Data)

Interpretation: From the above table 2.1 it can be seen clearly that Ease Global Reach $(20 \%)$ is the main reason for the women to start E-business. Next strong is that they have Profitability (15\%) followed by Greater Flexibility (13.33\%), Ease access of funds (13.33\%), Ease in communication (8\%), 24/7 Business (8\%), Absence of Middlemen (7\%), and Ability to do multitasks $(7 \%)$. Less favourable reasons are they have Tax Holiday for 3 years $(5 \%)$. And Faster processing of transaction (3\%). 


\subsubsection{Relationship between Education Qualification and Opportunities of Women Entrepreneurs in E-Commerce}

\section{Hypothesis}

$\mathrm{H}_{0}$ : There is no significant relationship between Education Qualification with Opportunities for women entrepreneurs in E-Commerce.

$\mathrm{H}_{1}$ : There is a significant relationship between Education Qualification with Opportunities for women entrepreneurs in E-Commerce.

Table 3 Showing Observed Frequencies

\begin{tabular}{|c|c|c|c|c|c|c|c|c|c|c|c|}
\hline \multirow{2}{*}{$\begin{array}{c}\text { Education } \\
\text { Qualificatio } \\
\text { n }\end{array}$} & \multicolumn{11}{|c|}{ Opportunities for Women Entrepreneurs in E-Commerce } \\
\hline & \begin{tabular}{|c|} 
Ease \\
Globa \\
1 \\
Reach
\end{tabular} & $\begin{array}{c}\text { Greater } \\
\text { Flexibilit } \\
\mathbf{y}\end{array}$ & $\begin{array}{c}\text { Profit } \\
\text { S }\end{array}$ & $\begin{array}{c}\text { No } \\
\text { Middleme } \\
\mathbf{n}\end{array}$ & $\underset{n}{\text { Ease in }} \underset{n}{\text { Communicatio }}$ & \begin{tabular}{|c|} 
Faster \\
Process of \\
Transactio \\
n
\end{tabular} & $\begin{array}{c}\text { Abilit } \\
\text { y to } \\
\text { do } \\
\text { multi } \\
\text { task }\end{array}$ & $\begin{array}{c}24 / 7 \\
\text { Busines } \\
\text { s }\end{array}$ & \begin{tabular}{|c|} 
Ease \\
acces \\
$s$ of \\
funds
\end{tabular} & \begin{tabular}{|c|} 
Tax \\
Holida \\
y for 3 \\
years
\end{tabular} & $\begin{array}{c}\text { Tota } \\
1\end{array}$ \\
\hline SSLC/ HSC & 3 & 2 & 2 & 0 & 0 & 0 & 0 & 1 & 2 & 0 & 10 \\
\hline $\begin{array}{l}\text { Under } \\
\text { Graduate }\end{array}$ & 1 & 1 & 1 & 3 & 5 & 2 & 2 & 4 & 6 & 2 & 27 \\
\hline \begin{tabular}{|l} 
Post \\
Graduate
\end{tabular} & 8 & 4 & 3 & 0 & 0 & 0 & 2 & 0 & 0 & 1 & 18 \\
\hline Professional & 0 & 1 & 3 & 1 & 0 & 0 & 0 & 0 & 0 & 0 & 5 \\
\hline Total & 12 & 8 & 9 & 4 & 5 & 2 & 4 & 5 & 8 & 3 & 60 \\
\hline
\end{tabular}

(source: Primary Data)

Table 4 Showing Expected Frequencies

\begin{tabular}{|c|c|c|c|c|c|c|c|c|c|c|c|}
\hline \multirow{2}{*}{$\begin{array}{c}\text { Education } \\
\text { Qualificatio } \\
\mathbf{n}\end{array}$} & \multicolumn{11}{|c|}{ Opportunities for Women Entrepreneurs in E-Commerce } \\
\hline & $\begin{array}{c}\text { Ease } \\
\text { Globa } \\
1 \\
\text { Reach }\end{array}$ & $\begin{array}{c}\text { Greater } \\
\text { Flexibilit } \\
\mathbf{y}\end{array}$ & $\begin{array}{c}\text { Profit } \\
\text { S }\end{array}$ & $\begin{array}{c}\text { No } \\
\text { Middleme } \\
\mathbf{n}\end{array}$ & $\begin{array}{c}\text { Ease in } \\
\text { Communicatio } \\
n\end{array}$ & $\begin{array}{c}\text { Faster } \\
\text { Process of } \\
\text { Transactio } \\
\text { n }\end{array}$ & $\begin{array}{c}\text { Abilit } \\
\text { y to } \\
\text { do } \\
\text { multi } \\
\text { task }\end{array}$ & $\begin{array}{c}24 / 7 \\
\text { Busines } \\
\text { s }\end{array}$ & \begin{tabular}{|c|} 
Ease \\
acces \\
$s$ of \\
funds
\end{tabular} & \begin{tabular}{|c|} 
Tax \\
Holida \\
y for 3 \\
years
\end{tabular} & $\begin{array}{c}\text { Tota } \\
1\end{array}$ \\
\hline SSLC/ HSC & 2 & 1.33 & 1.5 & 0.67 & .83 & 0.33 & 0.67 & 0.83 & 1.33 & 0.5 & 10 \\
\hline \begin{tabular}{|l} 
Under \\
Graduate
\end{tabular} & 5.4 & 3.6 & 4.05 & 1.8 & 2.25 & 0.9 & 1.8 & 2.25 & 3.6 & 1.35 & 27 \\
\hline $\begin{array}{l}\text { Post } \\
\text { Graduate }\end{array}$ & 3.6 & 2.4 & 2.7 & 1.2 & 1.5 & 0.6 & 1.2 & 1.5 & 2.4 & 0.9 & 18 \\
\hline Professional & 1 & 0.67 & 0.75 & 0.33 & 0.42 & 0.17 & 0.33 & 0.42 & 0.67 & 0.25 & 5 \\
\hline Total & 12 & 8 & 9 & 4 & 5 & 2 & 4 & 5 & 8 & 3 & 60 \\
\hline
\end{tabular}

(source: Primary Data)

\section{Chi-Square $(\chi 2)=46.68$}

$\mathrm{ndf}=(\mathrm{r}-1)(\mathrm{c}-1)=3 \mathrm{X} 9=27$

Table Value for $27 \mathrm{df}$ at $5 \%$ level $=40.113$

Interpretation: $\mathrm{H}_{0}$ is rejected . Since the calculated value is (46.68) is > (greater than) the table value (40.113). Hence, there is significant relationship Education Qualification of Women Entrepreneurs with Opportunities for women entrepreneurs in E-Commerce. 


\subsection{Challenges Faced by Women Entrepreneurs in E-Commerce sectors}

Generally, All Women Entrepreneurs face two category of problems namely Specific problems and General problems. Specific problems includes problem of arrangement of finance, limited mobility, lack of family support, lack of education, less risk bearing capacity etc. General problems includes lack of self-confidence, lack of recognition in society, cut-throat competition, and male dominated society. Here there are some of the problems faced by Women Entrepreneurs in E-Commerce Sector.

- Lack of Awareness: Each business has its own system. Likewise, E-Business has its own processes. Coming up with an idea is very difficult, obtaining domain name and website creation is difficult.

- Competitive Environment: Survival in E-Commerce Business is very difficult. There is a huge competition in almost all the products categories. High competition with lower profits enables Women Entrepreneurs to quit.

- Lack of Technologies Expertise: Starting a E-Business requires special set of skills like setting up websites, marketing products, employ specialised and qualified employees etc.

- Building credibility and Customer relationship is difficult: Gaining trust of customers is one of the biggest challenges in starting E-Business. Issues like privacy, security, Quality of products and services and customer buying decision based on Online image and Description.

- Promotion of Products and services: Attracting customers is major problem for Women Entrepreneur in E-Business. This includes advertising, articles, blogs, emails, you tube ads, content marketing etc.

Table 5 Challenges Faced by Women Entrepreneurs on E-Commerce

\begin{tabular}{|l|c|c|}
\hline \multicolumn{1}{|c|}{ Challenges of E-Commerce } & No. of Respondents & Percentage \\
\hline Difficulty in finding suitable market & 10 & $17 \%$ \\
\hline Security threats & 11 & $18 \%$ \\
\hline Privacy Issues & 7 & $7 \%$ \\
\hline Require huge investment & 4 & $8 \%$ \\
\hline Training the team & 5 & $7 \%$ \\
\hline Lack of technological skills & 4 & $5 \%$ \\
\hline Lack of ability & 3 & $13 \%$ \\
\hline Fear of Competitors & 8 & $3 \%$ \\
\hline Consistent update of websites & 2 & $10 \%$ \\
\hline Problems in retaining existing & 6 & $100 \%$ \\
customers & 60 & \\
\hline Total & & \\
\hline
\end{tabular}

(Source: Primary Data)

Interpretation: From the above given table 2.2, it is found that most Women Entrepreneurs faced the problem in doing E-Business in security Threats $(18 \%)$. The next problem is difficulty in finding suitable market (17\%), Fear of Competitors (13\%), Privacy Issues (12\%), Problems in retaining Existing customers (10\%), and Training the team (8\%). Less negative reasons are Requirement of huge investment (7\%), Lack of technological skills (7\%), Lack of ability (3\%), and Consistent update of Websites (3\%). 


\subsubsection{Relationship between Experience in E-Business and Challenges faced by Women Entrepreneurs in E-Business.}

\section{Hypothesis:}

$\mathrm{H}_{0}$ : There is no significant relationship between Experience and Challenges faced by Women Entrepreneurs in E- Business.

$\mathrm{H}_{1}$ : There is a significant relationship between Experience and Challenges faced by Women Entrepreneurs in E- Business.

Table 6 Showing Observed Frequencies

\begin{tabular}{|c|c|c|c|c|c|c|c|c|c|c|c|}
\hline \multirow{3}{*}{\begin{tabular}{|c|} 
Experienc \\
$\mathrm{e}$
\end{tabular}} & \multicolumn{11}{|c|}{ Challenges faced by Women Entrepreneurs in doing E-Business } \\
\hline & Difficult & Securit & Privac & Require & Trainin & Lack of & Lack & Fear of & Consiste & Problem & Tota \\
\hline & $\begin{array}{c}\mathrm{y} \text { in } \\
\text { finding } \\
\text { suitable } \\
\text { market }\end{array}$ & $\begin{array}{c}\mathbf{y} \\
\text { threats }\end{array}$ & $\begin{array}{c}\mathbf{y} \\
\text { issues }\end{array}$ & $\begin{array}{c}\text { huge } \\
\text { investme } \\
\text { nt }\end{array}$ & $\begin{array}{l}\text { g the } \\
\text { team }\end{array}$ & $\begin{array}{c}\text { Technologic } \\
\text { al Skills }\end{array}$ & $\begin{array}{c}\text { of } \\
\text { abilit } \\
y\end{array}$ & $\begin{array}{c}\text { Comoetito } \\
\text { rs }\end{array}$ & $\begin{array}{c}\text { nt } \\
\text { updation } \\
\text { of } \\
\text { websites }\end{array}$ & \begin{tabular}{|}
$\mathrm{s}$ in \\
retainin \\
$\mathrm{g}$ \\
Existing \\
custome \\
$\mathbf{r}$ \\
\end{tabular} & $\mathbf{l}$ \\
\hline $0-1$ Year & 3 & 6 & 4 & 2 & 1 & 1 & 2 & 2 & 1 & 1 & 23 \\
\hline $\begin{array}{l}1 \text { Year- } 2 \\
\text { years }\end{array}$ & 4 & 2 & 2 & 1 & 2 & 1 & 1 & 2 & 0 & 2 & 17 \\
\hline $\begin{array}{l}2 \text { years- } 4 \\
\text { years }\end{array}$ & 2 & 1 & 1 & 1 & 2 & 2 & 0 & 3 & 1 & 2 & 15 \\
\hline $\begin{array}{l}\text { Above } 4 \\
\text { years }\end{array}$ & 1 & 2 & 0 & 0 & 0 & 0 & 0 & 1 & 0 & 1 & 5 \\
\hline Total & 10 & 11 & 7 & 4 & 5 & 4 & 3 & 8 & 2 & 6 & 60 \\
\hline
\end{tabular}

(source: Primary Data)

Table 7 Showing Expected Frequencies

\begin{tabular}{|c|c|c|c|c|c|c|c|c|c|c|c|}
\hline \multirow{3}{*}{\begin{tabular}{|c|} 
Experienc \\
$\mathrm{e}$
\end{tabular}} & \multicolumn{11}{|c|}{ Challenges faced by Women Entrepreneurs in doing E-Business } \\
\hline & Difficult & Securit & Privac & Require & Trainin & Lack of & Lack & Fear of & Consiste & Problem & Tota \\
\hline & $\begin{array}{c}y \text { in } \\
\text { finding } \\
\text { suitable } \\
\text { market }\end{array}$ & $\begin{array}{c}\mathbf{y} \\
\text { threats }\end{array}$ & $\begin{array}{c}\mathbf{y} \\
\text { issues }\end{array}$ & $\begin{array}{c}\text { huge } \\
\text { investme } \\
\text { nt }\end{array}$ & $\begin{array}{l}\text { g the } \\
\text { team }\end{array}$ & $\begin{array}{c}\text { Technologic } \\
\text { al Skills }\end{array}$ & $\begin{array}{c}\text { of } \\
\text { abilit } \\
y\end{array}$ & $\begin{array}{c}\text { Comoetito } \\
\text { rs }\end{array}$ & $\begin{array}{c}\text { nt } \\
\text { updation } \\
\text { of } \\
\text { websites }\end{array}$ & \begin{tabular}{|}
$\mathrm{s}$ in \\
retainin \\
$\mathbf{g}$ \\
Existing \\
custome \\
$\mathbf{r}$
\end{tabular} & $\mathbf{l}$ \\
\hline $0-1$ Year & 3.83 & 4.23 & 2.68 & 1.53 & 1.92 & 1.53 & 1.15 & 3.07 & 0.77 & 2.3 & 23 \\
\hline $\begin{array}{l}1 \text { Year- } 2 \\
\text { years }\end{array}$ & 2.833 & 3.12 & 1.98 & 1.13 & 1.42 & 1.13 & 0.85 & 2.27 & 0.57 & 1.7 & 17 \\
\hline \begin{tabular}{|l|}
2 years- 4 \\
years \\
\end{tabular} & 2.5 & 2.75 & 1.75 & 1 & 1.25 & 2 & 0.75 & 2 & 0.5 & 1.5 & 15 \\
\hline \begin{tabular}{|l} 
Above 4 \\
years
\end{tabular} & 0.83 & 0.92 & 0.58 & 0.33 & 0.42 & 0.33 & 0.25 & 0.67 & 0.62 & 0.5 & 5 \\
\hline Total & 10 & 11 & 7 & 4 & 5 & 4 & 3 & 8 & 2 & 6 & 60 \\
\hline
\end{tabular}

(source: Primary Data)

\section{Chi-Square $(\chi 2)=14.949$}

ndf $=(\mathrm{r}-1)(\mathrm{c}-1)=3 \mathrm{X} 9=27$

Table Value for $27 \mathrm{df}$ at $5 \%$ level $=40.113$

Interpretation: $\mathrm{H}_{0}$ is accepted. Since, the calculated value is (14.949) is < (less than) the table value (40.113). Hence, there is no significant relationship between Experience and challenges face by Women Entrepreneurs in E-Business. 


\section{FINDINGS}

- From the above analysed data, it shows that, by accepting the null hypothesis $\left(\mathrm{H}_{0}\right)$ the Average age of the respondents belong to the age group of 25years- 30 years. Average Education Qualification of the respondents have SSLC/HSC. Average Martial status of the Respondents are Un Married., Average years of Experience of the respondent have in E Business is 1-2 years. Average Number of respondents are retailers in E-Business. Average Size of the E-Business is Micro level Business.

- Most of women (22\%) are involved in online clothing business followed by jewellery and cosmetics, Media and Entertainment, online teaching, catering services, Online Marketing and less involved in online health care services, Tourism services and consultancy activities.

By rejecting the null Hypothesis $\left(\mathrm{H}_{0}\right)$, Average kind of E-Business run by Women Entrepreneurs is not selling jewellery and cosmetics.

- The major opportunity faced by Women Entrepreneurs in E-Commerce is Ease Global Reach $(20 \%)$ is the main reason for the women to start E-business. Next strong is that they have Profitability (15\%) followed by Greater Flexibility (13.33\%), Ease access of funds $(13.33 \%)$, Ease in communication (8\%), 24/7 Business (8\%), Absence of Middlemen (7\%), and Ability to do multitasks (7\%). Less favourable reasons are they have Tax Holiday for 3 years (5\%), and Faster processing of transaction (3\%). The major challenge faced by Women Entrepreneurs in E-Commerce Business is Security Threats (18\%). The next problem is Difficulty in finding suitable market (17\%), Fear of competitors (13\%). Privacy Issues (12\%), Problems in retaining Existing customers $(10 \%)$ and Training the team $(8 \%)$. Less negative reasons are Require huge investment (7\%), Lack of Technological skills (7\%), Lack of ability (3\%) and Consistent update of websites (3\%).

- The interrelationship between Education Qualification and Opportunities of Ecommerce on Women Entrepreneurs clearly indicates that most of the Women Entrepreneurs (45\%) are under graduated and has major benefit (20\%) as Ease Global Reach. The Chi-Square results indicates that there is a high strength of association between Education Qualification and Opportunities for women entrepreneurs in doing E-Business.

- The interrelationship between Experience and challenges of E-commerce on Women Entrepreneurs clearly indicates that most of Women Entrepreneurs (38\%) have less than one year of experience and has major constraint (18\%) as Security Threats. The ChiSquare results indicates that there is no significant relationship between Experience and challenges faced by women entrepreneurs in doing E-Business.

\section{SUGGESTIONS}

For the development of Women Entrepreneurs in E-Commerce requires some efforts. The efforts has to be made to educate, inspire, encourage, motivate and co-operate Women Entrepreneurs in E-Business.

- An Awareness programmes can be conducted with the intention of creating awareness among Women about various opportunities to conduct E-Business.

- Organizing training programmes for developing Women to be professionally competence in E-Business, developing Managerial aspects, profit planning, leadership and other skills which encourage women entrepreneurs to carry out E-Business activities. 
- Vocational training can be conducted to enable Women Entrepreneurs to understand production process and production management.

- Academic institutes should be tie up with various Government and Non-Government agencies for Women Entrepreneurship Development.

- Women should be offered soft loans, interest free loans and subsidies for encouraging them to enter into E-Business.

- Encourage Women Entrepreneurs to do E-Business by conducting International and National level conferences, seminars, trade fairs and exhibitions at regular intervals.

- Financial Institutions should offer Working capital assistance for Women to start their own business.

- Women Entrepreneurs should be encouraged to start their business as Joint stock companies rather than sole proprietor and retailers concern to avail advantages of large scale operations.

To overcome challenges faced by Women Entrepreneurs in E-Commerce, various support has to be provided by Government and other private institutions.

Encouragement and motivations should be given to the Women to take the benefits of policy measures introduced by the government for promoting the status and level of Women Entrepreneurs in our society. Women also require support from their family and society. They should be provided ease financial help without putting unrealistic conditions by banks and financial institutions.

Security threats is the first major problem for Women Entrepreneurs in E-Commerce. Hence, Government has to take initiative in creating liaison with law and can start law enforcement agencies to help women to take entrepreneurial activity by understanding threats and trends in E-Commerce.

Fear of competitors and difficult in finding suitable market are the main problems for Women Entrepreneurs. So, Women Co-operative societies can be initiated to procure products from Women Entrepreneurs which help them in selling their products at reasonable price at perfect market.

\section{CONCLUSION}

In recent days, number of self-employed Women has been increasing rapidly due to advancement in technology. Women run their business not only for their survival but also to satisfy inner urge of creativity and ability to prove their capabilities.

This paper explores the relationship between 1)level of education qualification of Women Entrepreneurs and opportunities for Women Entrepreneurs in E-Commerce 2) Experience of Women Entrepreneurs in E-Business and challenges faced by them in E-Commerce. For this, cross tabulation was performed between the variables. The Chi-Square reveals that 1)Education qualification of Women Entrepreneurs doing online business has significant high strength of relationship with opportunities for Women Entrepreneurs in doing online business. 2) Experience of Women Entrepreneurs in doing online business has no significant relationship with challenges faced by Women Entrepreneurs in doing online business.

This indicates level of education qualification creates opportunities for Women Entrepreneurs in doing E-Commerce business. Education plays an important role in Women Entrepreneurship, as it pays ways to enhance innovative ability and personality and helps them to recognize various commercial opportunities, self-esteem, gains knowledge, and skills. And experience of Women Entrepreneurs in E-Business has no influence on challenges faced by them in E-Commerce 
Expand Business reach, Time and cost Saving, Increasing customer base, Rise in sales, 24/7 days, Cash less transaction, etc. are the opportunities faced by Women Entrepreneurs in ECommerce. Challenges faced by Women Entrepreneurs in E-Commerce are Lack of Awareness, Competitive Environment, Lack of Technologies Expertise, Building credibility and Customer relationship is difficult, Promotion of Products and services, Attracting customers etc. In this modern era, Women Entrepreneurs should sharpen their skills and knowledge according to latest technology. Since, E-Commerce enables Women Entrepreneurs in doing online business to achieve its mission and objectives.

\section{REFERENCES}

[1] Haniffah Haziqah Hussin, Mohd Azizee Jemari, Jati Kasuma, Yusman Yacob, Ratnawate Panie (2017) "Factors Influencing E-Commerce Adoption Among Malay Women Entrepreneurs In Kuching Sarawak"- Journal of Borneo Kalimantan JBK- Volume 3- Issue 1, DOI: https://doi.org/10.33736/jbk.614.2017

[2] Birgul Basarir-Ozel, Birgul Basarir-Ozel (2017)- "Factors affecting E-commerce adoption: A case of Turkey", The International Journal of Management Science and Information Technology (IJMSIT), Issue 23, ISSN 1923-0273, NAISIT Publishers, Toronto- PP. 1-11

[3] Paramitha Sur Ghosh (2021)- Impact of Higher Education on Women Empowerment in the present Era of Globalization" International Journal of Multi Disciplinary Educational Research ISSN:2277-7881; Impact Factor :6.514(2020); IC Value: 5.16; ISI Value:2.286 Peer Reviewed and Refereed Journal: Volume:10, Issue: 1(3), www.ijmer.in.

[4] Dr.V.S.Madana (2014)- "Women Empowerment: Some Issues", International Journal of Scientific Research, Volume: 3, Issue: 9, ISSN No 2277-8179, PP. 505-506.

[5] Dr.K.Prabavathy (2019)- "Women Entrepreneur and Digital Start-Ups", A Journal of Composition Theory, ISSN: 0731-6755, Volume XII Issue XII, PP. 502-507.

[6] SylviaMaier, Usha Nair- Reicheri (2007)- "Empowering Women through ICT- Based Business initiatives: An Overview of Best Practices in E-Commerce/E-Retailing Projects", Information Technologies and International Development, Volume 4, Number 2, PP. 43-60.

[7] Eunice Mukolwe, Dr. Jacqueline Korir (2016)- "Social Media and Entrepreneurship: Tools, Benefits, and Challenges. A Case Study of Women Online Entrepreneurs on Kilimani Mums Marketplace on Facebook", International Journal of Humanities and Social Science, Vol. 6, No. 8, ISSN 2220-8488 (Print), 2221-0989 (Online), PP. 248-256, www.ijhssnet.com.

[8] Dr. Mita Ashish Shah (2017)- "Empowerment and Transformation of Women Entrepreneurs through Digital India Drive." Anveshana 7,PP. 14-27.

[9] Dr. Dharmendra Mehta, Er. Sunayana Soni \& Dr Naveen K Mehta - Women Entrepreneurs in E-Commerce: An Indian Perspective." Altius Shodh Journal of Management and Commerce, ISSN 2348-8891.

[10] Dr. R. Radhika Ravi, N. Soundarya (2016) - "E-Commerce- A Tool of Women Empowerment" International Journal of Advanced Scientific Research and Development, p ISSN-2394-8906, e-ISSN 2395-6089, Impact Factor: 2.415, Volume-03, Special Issue- 02, PP. 353-358, http://www.ijasrd.org/in

[11] Manisha Parnami, Tripti Bisawa: The Rise of Indian Women Entrepreneur E commerce, IOSR Journal of Business and Management (IOSR-JBM) e-ISSN: 2278-487X, p ISSN: 2319-7668. Volume 17, Issue 10.Ver. I (Oct. 2015), PP 36-40 